\title{
PEMBELAJARAN KONTEKSTUAL UNTUK MENINGKATKAN AKTIVITAS DAN HASIL BELAJAR SISWA DALAM PEMBELAJARAN EKONOMI
}

\author{
Ira Kurniati, ${ }^{\bowtie}$ Fahimul Amri
}

Pendidikan Ekonomi STKIP PGRI Jombang

\section{Info Artikel}

Sejarah Artikel:

Diterima 16 April 2020

Disetujui 23 Juni 2020

Dipublikasikan 31

Agustus 2020

\section{Keywords:} contextual learning, economic learning, learning activities, student achievement

\begin{abstract}
Abstrak
Penelitian ini bertujuan untuk meningkatkan aktivitas dan hasil belajar siswa dalam proses pembelajaran ekonomi di sekolah dengan menerapkan pembelajaran kontekstual. Penelitian ini menggunakan desain penelitian tindakan kelas melalui tahapan perencanaan, pelaksanaan, pengamatan, dan refleksi. Penerapan tindakan dilakukan dalam dua siklus, dan masingmasing siklus dilakukan dalam empat pertemuan pembelajaran. Subjek dalam penelitian ini adalah siswa kelas X IPS 2 di MAN 9 Jombang yang berjumlah 40 orang. Pengumpulan data dilakukan dengan menggunakan instrumen angket, wawancara, observasi, dokumentasi, dan tes. Analisis data dilakukan secara deskriptif dengan teknik persentase untuk menjelaskan temuan penelitian. Hasil penelitian menunjukkan bahwa penerapan pembelajaran kontekstual dalam pembelajaran ekonomi dapat meningkatkan aktivitas dan hasil belajar siswa, yang ditunjukkan dari peningkatan aktivitas siswa selama proses diskusi dan presentasi hasil. Direkomendasikan kepada guru ekonomi agar dapat menerapkan pembelajaran kontekstual dalam proses pembelajaran ekonomi di sekolah
\end{abstract}

\section{Abstract}

This study aims to improve the activities and student learning outcomes in the economic learning process in schools by applying contextual learning. This study used a classroom action research design through the stages of planning, implementation, observation, and reflection. The application of action is carried out in two cycles, and each cycle is carried out in four learning meetings. The subjects in this study were 40 students of class X IPS 2 in MAN 9 Jombang. Data collection was carried out using questionnaire instruments, interviews, observations, documentation, and tests. Data analysis was performed descriptively with percentage techniques to explain the research findings. The results showed that the application of contextual learning in economic learning can improve student learning activities and student achievement, which is shown from the increase in student activity during the process of discussion and presentation of results. It is recommended to economics teachers to be able to apply contextual learning in the process of economic learning in schools.

\begin{tabular}{ll}
\hline Alamat korespondensi: & p-ISSN 2723-4495 \\
STKIP PGRI Jombang & e-ISSN 2723-4487 \\
E-mail: irakurniati2016@gmail.com &
\end{tabular}




\section{PENDAHULUAN}

Guru memiliki posisi yang strategis untuk mewujudkan pembelajaran yang efektif. Guru yang profesional dituntut untuk menerapkan berbagai strategi dan metode pembelajaran yang menyenangkan, kontekstual, dan bermakna. Proses pendidikan yang dikelola dengan sempurna dan ditunjang guru yang profesional akan menghasilkan kualitas pendidikan yang baik pula (Mulyasa, 2007).

Penggunaan strategi atau metode pembelajaran yang diterapkan oleh guru untuk menciptakan pembelajaran yang efektif harus berpusat pada siswa.Siswa harus menjadi pusat belajar. Guru dituntut untuk terampil dalam mengaplikasikan metode pembelajaran yang mampu mengaktifkan siswa dalam proses pembelajaran. Disamping itu, agar proses pembelajaran lebih bermakna, guru harus secara kreatif melaksanakan pembelajaran yang berorientasi pada kehidupan nyata atau kontekstual. Melalui penggunaan strategi atau metode pembelajaran yang berpusat pada siswa dan kontekstual, dapat membuat pembelajaran semakin bermakna dan menyenangkan.

Guru ekonomi harus berperan lebih untuk mengubah pembelajaran ekonomi menjadi lebih kreatif, terutama pembelajaran yang berorientasi kontekstual, agar siswa lebih termotivasi, aktif, kreatif, dan semakin senang dalam belajar ekonomi. Proses pembelajaran idealnya tidak hanya diarahkan sebagai upaya untuk mendapatkan pengetahuan sebanyak-banyaknya, tetapi juga bagaimana menerapkan pengetahuan yang didapatkan untuk menyelesaikan permasalahan dalam aktivitas kehidupan seharihari. Melalui proses pembelajaran seperti ini, dapat melatih siswa untuk mengatasi masalah dan menghubungkan teori yang diperoleh dengan kehidupan nyata sehari hari. Pengalaman pembelajaran tersebut sangat bermanfaat bagi siswa untuk mereka pelajari di dalam kelas dan dapat diterapkan dalam kehidupan nyata.

Kenyataan yang terjadi selama ini dalam pembelajaran ekonomi lebih didominasi oleh guru. Guru lebih banyak ceramah dan siswa hanya mendengarkannya. Guru ekonomi dalam melaksanakan pembelajarannya lebih banyak bersifat teoritis dan hafalan. Fakta tersebut juga masih terjadi di MAN 9 Jombang. Berdasarkan wawancara dan pemberian angket kepada siswa kelas X di MAN 9 Jombang menunjukkan bahwa proses pembelajaran yang diterapkan oleh guru ekonomi lebih banyak bersifat teoritis, lebih banyak menghafal materi pelajaran, dan kurang menghubungkan kondisi nyata sesuai dengan kehidupan sehari-hari siswa. Dampaknya adalah siswa kurang termotivasi untuk belajar, kurang aktif dalam belajar, kurang kreatif, kurang senang untuk belajar ekonomi jika dibandingkan materi pelajaran lainnya, kurang memiliki kemampuan menyelesaikan masalah ekonomi secara kontekstual. Pembelajaran ekonomi harus mampu membawa siswa untuk belajar secara langsung dengan mengaitkan materi yang dipelajari dengan aktivitas ekonomi yang ada disekitar kehidupan mereka. Salah satu strategi atau metode pembelajaran yang dapat diterapkan adalah pembelajaran kontekstual. Oleh karena itu dalam penelitian ini guru ekonomi menerapkan pembelajaran kontekstual dalam upaya meningkatkan keaktifan dan hasil belajar siswa dalam pelajaran ekonomi

Pembelajaran kontekstual merupakan pembelajaran holistik yang bermakna, yang menghubungkan materi pelajaran dengan kehidupan nyata sehari-hari dalam konteks lingkungan pribadi, agama, sosial, ekonomi, maupun budaya yang ada di sekitar siswa (Kunandar, 2007; Hanafiah \& Suhana, 2012). Sanjaya (2008) juga mengungkapkan bahwa pembelajaran kontekstual merupakan suatu strategi pembelajaran yang menekankan proses keterlibatan siswa secara penuh untuk dapat menemukan materi yang dipelajarinya dan menghubungkannya dengan situasi kehidupan nyata sehingga mendorong siswa untuk menerapkannya dalam kehidupan mereka. Hal yang sama juga diungkapkan oleh Aqib (2013); Johnson (2002); Komalasari (2010); Nurhadi. \& Senduk (2003); Trianto (2012) bahwa pembelajaran kontekstual merupakan pembelajaran yang membantu guru mengaitkan antara materi yang diajarkannya dengan situasi dunia nyata siswa, serta mendorong siswa untuk dapat membuat hubungan antara pengetahuan yang dimiliki dengan penerapannya dalam kehidupan sehari-hari.

Selain itu, Johnson (2002); Kunandar (2007); Nurhadi\& Senduk (2003) 
mengungkapkan bahwa pembelajaran kontekstual mempunyai karakteristik sebagai berikut: (1) dilaksanakan dalam konteks autentik dengan membuat hubungan antara materi pelajaran dengan berbagai konteks yang ada dalam kehidupan nyata, (2) memberikan kesempatan dan memberikan pengalaman bermakna kepada siswa, (4) dilaksanakan melalui kerja kelompok dan berdiskusi, (5) memberikan kesempatan untuk menciptakan rasa kebersamaan, bekerja sama, dan saling memahami antara satu dengan yang lain secara mendalam, (6) dilaksanakan secara kritis, aktif, kreatif, produktif, dan mementingkan kerja sama, (7) dilaksanakan dalam situasi yang menyenangkan, (7) menggunakan penilaian autentik, (8) belajar dapat diatur sendiri, (9) memelihara pribadi siswa, (10) menetapkan standar yang tinggi. Disamping itu dalam pembelajaran kontekstual mempunyai tujuh komponen utama yaitu konstruktivisme, menemukan, bertanya, masyarakat belajar, pemodelan, refleksi, adanya penilaian yang sebenarnya (Komalasari, 2010; Nurhadi\& Senduk,2003; Trianto, 2007).

Beberapa penelitian tentang penggunaan atau penerapan pembelajaran kontekstual telah dilakukan.Temuan Nurhidayah\& Nurlina, (2016) menunjukkan bahwa hasil belajar siswa meningkat setelah guru menerapkan model pembelajaran kontekstual. Susiloningsih (2016) dalam penelitiannya juga menunjukkan bahwa pembelajaran kontekstual mampu meningkatkan prestasi belajar siswa. Hal yang sama juga ditunjukkan dari penelitian yang dilakukan oleh Lilia \& Widodo (2014) yang hasilnya menunjukkan bahwa implementasi pembelajaran kontekstual memberikan perbedaan yang positif terhadap hasil belajar siswa dalam mata pelajaran kimia. Penelitiannya Sung dkk., (2019) juga menunjukkan hasil bahwa sebuah sistem ebook interaktif yang dikembangkan berdasarkan pembelajaran kontekstual dapat meningkatkan prestasi belajar siswa dan meningkatkan motivasi siswa dalam belajar. Berdasarkan hasil penelitian tersebut menunjukkan bahwa pembelajaran kontekstual dapat meningkatkan prestasi atau hasil belajar siswa.

Penelitian yang serupa juga dilakukan oleh Santoso (2017) yang menunjukkan hasil bahwa terdapat perbedaan kemampuan pemahaman matematik siswa sebelum dan sesudah pembelajaran menggunakan model pembelajaran kontekstual.Selain itu, temuan Retnanto (2016) juga menunjukkan bahwa pembelajaran kontekstual memberikan dampak bagi mahasiswa terutama mahasiswa lebih mudah memahami konsep yang abstrak, dan mampu meningkatkan kemampuan siswa dalam menulis karangan eksposisi.

Penelitian yang lain juga menunjukkan bahwa pembelajaran kontekstual tidak hanya dapat meningkatkan prestasi belajar tetapi juga dapat memberikan dampak bagi peningkatan kemampuan lain pada diri siswa. Pembelajaran kontekstual mampu memberikan dampak yang lebih baik terhadap peningkatan kecakapan hidup personal dan kecakapan hidup sosial siswa (Pulungan dkk., 2013), memberikan efek bagi pengembangan kecakapan hidup termasuk karakter siswa (Komalasari, 2012).

Berdasarkan beberapa penelitian tersebut, dalam konteks pembelajaran ekonomi perlu diterapkan pembelajaran yang kontekstual sebagai salah satu cara untuk menyelesaikan permasalahan pembelajaran ekonomi. Sehingga pembelajaran yang dilaksanakan oleh guru lebih bermakna, menyenangkan, dan pada akhirnya dapat meningkatkan kreatifitas, aktivitas, dan prestasi belajar siswa.

\section{METODE}

Penelitian ini menggunakan desain penelitian tindakan kelas (PTK) (Koshy, 2005). Prosedur penelitian tindakan kelas yang dilakukan meliputi perencanaan, pelaksanaan tindakan dan pengamatan, serta refleksi.Penelitian tindakan kelas ini dilakukan dalam dua siklus. Masing-masing siklus dilaksanakan selama empat kali pertemuan termasuk kegiatan postest. Penelitian tindakan kelas dilaksanakan di MAN 9 Jombang. Subjek dalam penelitian ini adalah siswa kelas X IPS 2 yang berjumlah 40 orang yang sedang menempuh mata pelajaran ekonomi tentang uang dan lembaga keuangan.Penentuan subjek penelitian ini berdasarkan hasil investigasi terhadap proses pembelajaran yang telah dilaksanakan dalam pembelajaran ekonomi, yaitu pembelajaran yang diterapkan belum 
kontekstual, sehingga efektifitas pembelajaran ekonomi belum maksimal.

Instrumen yang digunakan untuk mengumpulkan data dalam penelitian tindakan kelas ini yaitu angket, wawancara, pedoman observasi, dokumentasi, dan soal tes. Angket dan wawancara digunakan untuk memperoleh data awal tentang pembelajaran yang dilaksanakan sebelum PTK diterapkan. Pedoman observasi digunakan untuk mengumpulkan data pada saat pelaksanaan pembelajaran, baik kepada guru maupun kepada siswa. Sedangkan soal tes digunakan untuk mendapatkan hasil belajar siswa sebelum dan setelah mengikuti kegiatan pembelajaran kontekstual yang diterapkan oleh guru.

Kegiatan yang dilakukan dalam tahap perencanaan sebagai berikut: (1) menyusun rencana perbaikan pembelajaran untuk setiap pertemuan yang didalamnya memuat skenario pembelajaran sesuai dengan strategi yang dipilih yaitu pembelajaran kontekstual melalui metode diskusi, observasi ke lapangan (ke lembaga keuangan) dan presentasi hasil observasi, (2) menyusun lembar kerja siswa (LKS) sesuai dengan kegiatan pembelajaran pada setiap pertemuan. LKS hanya dapat dikerjakan oleh siswa melalui kegiatan observasi, (3) membentuk kelompok diskusi dan observasi yang beranggotakan 5-6 siswa, (4) menyusun instrumen pengumpul data yang berbentuk tes untuk pretest dan postes (termasuk menyusun kisi-kisi soal dan pedoman penilaian) dan non tes (pedoman observasi, lembar penilaian laporan) untuk siswa, dan pedoman observasi untuk kinerja guru selama PTK berlangsung.

Selanjutnya pada tahap pelaksanaan tindakan, guru melaksanakan kegiatan pembelajaran kontekstual sesuai rencana perbaikan yang telah disusun. Kegiatan yang dilakukan selama empat pertemuan pada setiap siklus meliputi (1) penilaian performance siswa dan pretes, (2) penilaian kinerja dalam diskusi, (3) penilaian kinerja siswa dalam observasi dan penilaian proyek, (4) penilaian kinerja dalam presentasi dan postes.

Selanjutnya tahap observasi dilaksanakan oleh guru dan berkolaborasi dengan rekan sejawat untuk mengamati aktivitas siswa selama proses pembelajaran. Selain itu rekan sejawat juga untuk mengamati aktivitas yang dilaksanakan oleh guru selama proses pembelajaran. Pada tahap observasi, guru maupun rekan sejawat yang bertugas sebagai pengamat menggunakan pedoman observasi yang telah dibuat.

Tahap terakhir adalah refleksi yang dilakukan disetiap pertemuan, baik dalam siklus satu maupun siklus dua.Setelah pelaksanaan pembelajaran berakhir pada setiap pertemuan.Tahap refleksi merupakan tahap perenungan terhadap segala hal yang terjadi selama tindakan pembelajaran berlangsung.Selain itu dalam tahap refleksi guru juga berdiskusi dengan rekan sejawat yang bertugas sebagai pengamat untuk mengetahui temuan-temuan selama tindakan pembelajaran.Berdasarkan hasil refleksi menjadi dasar untuk melakukan perbaikan pada pertemuan maupun siklus selanjutnya.Hasil refleksi siklus ke satu digunakan sebagai acuan dalam menentukan perbaikan tindakan pada siklus ke dua.

Tahapan pelaksanaan tindakan kelas pada siklus ke dua pada prinsipnya sama dengan pelaksanaan pada siklus ke satu. Namun pelaksanaan pembelajarannya memperbaiki dari kelemahan yang ditemukan selama pelaksanaan pembelajaran pada siklus ke satu, termasuk memperbaiki perencanaan pembelajaran dan memperbaiki instrumen pengumpul data.

Analisis data dilakukan secara deskriptif dengan menggunakan teknik persentase. Analisis deskriptif dilakukan berdasarkan hasil observasi, hasil angket, hasil wawancara, dan studi dokumentasi hasil kerja siswa. Pengambilan keputusan berdasarkan pada pada ketercapaian indikator keberhasilan yang telah ditentukan. Kriteria atau indikator keberhasilan yang telah ditentukan dalam penelitian tindakan kelas ini sebagai berikut: (1) hasil belajar meningkat jika skor postes siklus ke satu meningkat dari pretes dan skor postes siklus ke dua meningkat dari postes siklus ke satu, dengan standar ketuntasan belajar secara individu sebesar $\geq 70$, (2) aktivitas siswa selama proses pembelajaran berlangsung melalui diskusi dan presentasi dengan standar ketuntasan secara kelas $>70$, (3) laporan hasil kerja memenuhi standar ketuntasan secara kelas $>70$, (4) berdasarkan angket, respon siswa 
menyatakan setuju dengan tindakan pembelajaran kontekstual tentang uang dan lembaga keuangan sebesar $\geq 75 \%$.

\section{HASIL DAN PEMBAHASAN}

1. Pembelajaran pada siklus ke satu

Pembelajaran siklus satu dilakukan selama empat kali pertemuan. Pertemuan pertama kegiatan diawali dengan menyampaikan informasi tentang konsep dasar uang dan lembaga keuangan. Informasi dilanjutkan dengan pembelajaran ekonomi yang akan dilakukan adalah pembelajaran kontekstual dengan observai ke beberapa lembaga keuangan, yakni : bank pemerintah, bank swasta, dan lembaga non bank.

Dalam kesempatan tersebut, pembelajaran dilakukan melalui informasi dan tanya jawab antara guru dan siswa, guru banyak mengomentarkan masalah-masalah yang kontekstual untuk diselesaikan oleh siswa. Guru melakukan penilaian terhadap aktivitas siswa dalam proses pembelajaran ini dengan menggunakan lembar pengamatan dalam proses pembelajaran.

Pada pertemuan pertama guru juga menginformasikan serta memberi motivasi bahwa pembelajaran tentang uang dan lembaga keuangan tidak hanya dilakukan secara teoritis saja, tetapi perlu mendapat pengalaman langsung dari lapangan tentang kegiatan lembaga keuangan bank dan non bank, melihat bukti bukti transaksi yang digunakan. Siswa perlu memiliki kemampuan untuk mengkonstruksi berdasarkan pengetahuan dan pengalamannya di lapangan yang dilakukan melalui observasi di lapangan.

Pada pertemuan ke dua pembelajaran difokuskan kepada aktivitas diskusi untuk mengerjakan Lembar Kerja Siswa (LKS) dan persiapan mengadakan observasi ke lapangan yang harus dilakukan siswa. Guru membagi kelas menjadi delapan kelompok, dan membagikan 3 jenis LKS yakni LKS A, LKS B, dan LKS C.

LKS A garis besarnya berisi tugas yang harus diselesaikan siswa berdasarkan pembelajaran kontekstual yakni siswa diminta untuk menyusun atau mengkonstruksi sendiri pengetahuan dari hal yang dilihat dan dialaminya dalam observasi di lapangan. Pembelajaran ini difokuskan untuk mengamati aktivitas kegiatan yang ada di bank pemerintah. LKS B garis besarnya berisi tugas pembelajaranyang difokuskan mengamati aktivitas kegiatan yang ada di bank swasta. Sedangkan LKS C garis besarnya berisi tugas yang harus diselesaikan siswa yang difokuskan pada mengamati kegiatan lembaga non bank, yakni koperasi.

Berdasarkan kegiatan diskusi siswa tersebut, guru melakukan pengamatan (observasi) proses pelaksanaan diskusi dengan menggunakan instrumen observasi. Berdasarkan hasil observasi dapat ditampilkan nilai kinerja siswa di dalam diskusi, dan analisis data nilai siswa sebagai berikut:

Tabel 1. Penilaian kinerja siswa dalam diskusi kelompok

\begin{tabular}{|c|c|c|c|c|c|c|}
\hline \multirow{2}{*}{$\begin{array}{c}\text { Kelom } \\
\text { pok }\end{array}$} & \multicolumn{5}{|c|}{ Aspek yang dinilai } & \multirow{2}{*}{$\begin{array}{c}\text { Rata-rata } \\
\text { perkelompok }\end{array}$} \\
\hline & $\mathrm{A}$ & $\mathrm{B}$ & $\mathrm{C}$ & $\mathrm{D}$ & $\mathrm{E}$ & \\
\hline 1 & 66.8 & 67.4 & 67 & 63.2 & 68.6 & 66.6 \\
\hline 2 & 66.4 & 70.6 & 69.6 & 68.4 & 66.8 & 68.36 \\
\hline 3 & 66.2 & 67 & 68.4 & 70.2 & 68.2 & 68 \\
\hline 4 & 68.6 & 65.2 & 66.8 & 70.6 & 66.2 & 67.48 \\
\hline 5 & 68 & 68.4 & 66.6 & 64.6 & 65.8 & 66.68 \\
\hline 6 & 67.2 & 62.8 & 69 & 69.2 & 65.2 & 66.68 \\
\hline 7 & 70.2 & 66.6 & 67.2 & 66 & 65 & 67 \\
\hline 8 & 67.2 & 65.4 & 65.4 & 68 & 70 & 67.2 \\
\hline $\begin{array}{l}\text { Rata- } \\
\text { rata }\end{array}$ & 67.58 & 66.68 & 67.50 & 67.53 & 66.98 & 67.25 \\
\hline
\end{tabular}

Keterangan:

A: kerjasama

B: kemampuan berpendapat

C: kemampuan menerima pendapat

D: kualitas berargumentas

E:kemampuan membuat kesimpulan hasil diskusi

Berdasarkan tabel 1 bahwa skor rata-rata aspek yang dinilai untuk semua kelompok dalam satu kelas sebesar 67.25. Rata-rata tertinggi apsek yang dinilai berada pada aspek A. Sedangkan rata-rata terendah pada aspek B. Kelompok yang mendapatkan skor rata-rata terendah untuk semua aspek adalah kelompok 1, sedangkan kelompok yang mendapatkan skor rata-rata tertinggi adalah kelompok 2. Berdasarkan kriteria keberhasilan yang telah ditentukan 
menggunakan standar ketuntasan nilai diskusi $(>70)$, maka secara kelas dianggap belum tuntas. Selain itu dari 40 siswa yang mengikuti proses pembelajaran yang memiliki nilai proses diskusi $>70$ atau dinyatakan tuntas hanya 1 siswa atau hanya 2,50\% dari seluruh siswa.

Berdasarkan pengamatan selama pelaksanaan pembelajaran, maka dalam kegiatan refleksi diperoleh beberapa kesimpulan yaitu kemampuan siswa untuk menyampaikan pendapat masih perlu ditingkatkan, Siswa yang aktif dalam diskusi hanya sebagian, kemampuan siswa dalam menjawab pertanyaan belum merata, dan siswa masih kesulitan dalam menyimpulkan hasil diskusi.

Selanjutnya dalam pelaksanaan pembelajaran pada pertemuan ketiga difokuskan pada kegiatan presentasi yang dilakukan siswa didepan kelas untuk melaporkan hasil kerja kelompok. Dalam kegiatan presentasi ini masingmasing kelompok diwakili oleh dua orang. Kelompok 1, 2, dan 3 melaporkan hasil tentang aktifitas lembaga keuangan pemerintah. Kelompok 4, 5, 6 melaporkan hasil observasi tentang aktifitas lembaga keuangan bank swasta. Kelompok 7 dan 8 melaporkan hasil observasi tentang aktifitas lembaga keuangan non bank yakni koperasi.

Guru melakukan pengamatan terhadap presentasi siswa dan keaktifan siswa di dalam kelas dalam menerima dan menanggapi pertanyaan atau pendapat dari teman yang lain. Guru menggunakan pedoman pengamatan untuk mengamati presentasi siswa. Berdasarkan pengamatan yang telah dilakukan menunjukkan hasil penilaian kinerja siswa dalam presentasi ditunjukkan dalam tabel berikut:

Tabel 2. Penilaian kinerja siswa dalam presentasi

\begin{tabular}{ccccccc}
\hline \multirow{2}{*}{$\begin{array}{c}\text { Kelom } \\
\text { pok }\end{array}$} & $\mathrm{A}$ & $\mathrm{B}$ & $\mathrm{C}$ & $\mathrm{D}$ & $\mathrm{E}$ & $\begin{array}{c}\text { Rata- } \\
\text { rata }\end{array}$ \\
\cline { 2 - 6 } & 67 & 66 & 67.2 & 68 & 67.2 & 67.08 \\
1 & 67.2 & 69.2 & 64.8 & 67.2 & 67.2 & 67.72 \\
2 & 70.2 & 67.8 & 66.6 & 67.24 \\
3 & 68.2 & 66.6 & 67 & 67.8 & 69.2 \\
4 & 67.6 & 70.8 & 66.4 & 70.8 & 70.2 & 69.16 \\
5 & 69.2 & 67.2 & 68.4 & 71.8 & 68.2 & 68.96 \\
6 & 64.6 & 67.2 & 68 & 66.6 & 69.4 & 67.16 \\
7 & 73 & 69.2 & 70.4 & 69 & 66 & 69.52 \\
8 & 66 & 66.2 & 69.6 & 65.6 & 65.2 & 66.52 \\
\hline
\end{tabular}

\begin{tabular}{ccccccc}
$\begin{array}{c}\text { Rata- } \\
\text { rata }\end{array}$ & 68.23 & 67.80 & 67.73 & 68.35 & 67.50 & 67.92 \\
\hline
\end{tabular}

Keterangan:

A:kerja sama

B:sistematika berbicara

C:kemampuan mengikuti presentasi

D:kualitas isi presentasi

E:kemampuan membuat kesimpulan

Berdasarkan tabel 2 bahwa skor rata-rata untuk semua aspek dalam satu kelas selama melaksanakan prestasi adalah sebesar 67.92. Rata-rata tertinggi apsek yang dinilai berada pada aspek C. Sedangkan rata-rata terendah pada aspek E. Kelompok yang mendapatkan skor ratarata terendah untuk semua aspek adalah kelompok 1, sedangkan kelompok yang mendapatkan skor rata-rata tertinggi adalah kelompok 7. Kelompok yang mendapatkan skor terendah pada salah satu aspek adalah kelompok 6 (aspek A), sedangkan kelompok yang mendapatkan skor tertinggi pada salah satu aspek adalah kelompok 7 (aspek A).

Berdasarkan kriteria keberhasilan yang telah ditentukan menggunakan standar ketuntasan nilai presentasi ( $>70)$, maka secara kelas dianggap belum tuntas. Selain itu dari 40 siswa yang mengikuti proses pembelajaran yang memiliki nilai proses presentasi $>70$ atau dinyatakan tuntas hanya 10 siswa atau hanya 25 $\%$ dari seluruh siswa.

Setelah presentasi 8 kelompok selesai dilaksanakan, guru menanggapi secara umum hasil presentasi yang dilakukan masing-masing kelompok. Kemudian memberikan umpan balik atas pelaksanaan presentasi, serta memberikan penjelasan untuk perbaikan laporan yang akan dikumpulkan. Berikutnya guru memerintahkan kepada siswa untuk merevisi laporan hasil kerja kelompok.

Berdasarkan pengamatan selama pelaksanaan pembelajaran, maka dalam kegiatan refleksi diperoleh beberapa kesimpulan yaitu kemampuan siswa untuk presentasi masih perlu ditingkatkan, siswa yang aktif dalam presentasi hanya sebagian, kemampuan siswa dalam bertanya dan menjawab pertanyaan belum merata, dan siswa masih kesulitan dalam presentasi dengan sistematika yang baik.

Selanjutnya dalam pertemuan ke empat, guru melakukan penilaian terhadap laporan hasil 
kerja masing-masing kelompok dengan postes serta masukan dari observer. Kelebihanmenggunakan format penilaian proyek (hasil kelebihan yang ditemukan selama melaksanakan kerja kelompok tentang aktivitas dan peranan tindakan akan terus diterapkan dan tiga jenis badan usaha yakni bank pemerintah, dikembangkan, dan sebaliknya kelemahan yang bank swasta, dan koperasi). Selain itu guru juga muncul akan diperbaiki pada pertemuan siklus melakukan kegiatan post test untuk melihat berikutnya. Kelebihan selama pelaksanaan pencapaian hasil belajar siswa. pembelajaran dalam siklus satu yaitu: (1) partisipasi siswa saat pembelajaran sudah mulai

Tabel 3. Penilaian proyek laporan hasil observasi nampak jika dibandingkan sebelum diadakan kerja kelompok

\begin{tabular}{lcccccc}
\hline \multicolumn{7}{c}{ Aspek yang Dinilai } \\
Kelompok & A & B & C & D & E & Rata \\
\hline 1 & 63 & 63 & 72 & 64 & 66 & 65.6 \\
2 & 63 & 63 & 70 & 66 & 66 & 65.6 \\
3 & 63 & 68 & 72 & 62 & 62 & 65.4 \\
4 & 65 & 66 & 70 & 64 & 62 & 65.4 \\
5 & 74 & 65 & 62 & 72 & 69 & 68.4 \\
6 & 73 & 66 & 61 & 73 & 70 & 68.6 \\
7 & 70 & 64 & 62 & 62 & 70 & 65.6 \\
8 & 66 & 68 & 66 & 62 & 66 & 65.6 \\
\hline
\end{tabular}
PTK, (2) siswa disiplin dan bersemangat dalam belajar termasuk mengerjakan tugas (berdasarkan pengakuan siswa dalam mengerjakan tugas kelompok), (3) siswa nampak bergembira selama mengikuti pembelajaran, (4) Kegembiraan ini berdampak kepada semangat belajar siswa, (5) guru sudah mampu memfasilitasi proses pembelajaran, (6) materi yang dibahas bersifat kontekstual, dan (7) guru telah memberi motivasi yang cukup bermakna bagi siswa, dalam bentuk pemberian reward berupa stiker dan hadiah kepada siswa yang berhasil.

Selain kelebihan, kelemahan dalam proses

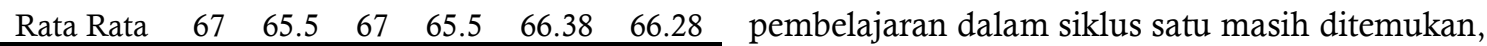
Keterangan:

A: kelengkapan isi laporan

B: sistematika laporan

C: kualitas laporan

D: penggunaan bahasa

E: relevansi dengan tugas

Berdasarkan tabel 3, skor rata-rata untuk semua aspek dalam satu kelas untuk hasil laporan adalah sebesar 66.28. Kelompok yang mendapatkan skor rata-rata terendah untuk semua aspek adalah kelompok 3 dan 4 , sedangkan kelompok yang mendapatkan skor rata-rata tertinggi adalah kelompok 5 dan 6 . Berdasarkan kriteria keberhasilan dengan menggunakan standar ketuntasan nilai laporan pada siklus I $(>70)$, maka secara kelas dianggap belum tuntas. Selain itu semua kelompok memiliki nilai laporan kurang dari 70 atau dinyatakan belum tuntas.

Setelah pelaksanaan pembelajaran dalam siklus satu berakhir, maka guru beserta rekan sejawat sebagai observer atau pengamat melakukan refleksi untuk mengetahui kekurangan dan kelebihan selama pelaksanaan pembelajaran dalam siklus I. Refleksi ini didasarkan pada hasil observasi, hasil angket,hasil wawancara, dokumentasihasil kerja siswa, nilai pretes dan beberapa kelemahan selama melaksanakan pembelajaran dalam siklus satu sebagai berikut: (1) proses diskusi dalam pembelajaran skor penilaian skor masih dibawah 70 , dan belum tuntas (hanya 2,50\% yang tuntas), (2) proses presentasi siswa dalam pembelajaran skor penilaiannya masih dibawah 70 , dan belum tuntas (hanya $25 \%$ yang tuntas), dan (3) nilai laporan hasil hasil kerja kelompok dalam pembelajaran skor penilaiannya masih di bawah 70 atau belum tuntas ( $0 \%$ yang tuntas).

Berdasarkan pada hasil refleksi yang telah dilakukan, maka selanjutnya adalah menentukan pelaksanaan siklus ke dua. Sebelum pelaksanaan pembelajaran pada siklus kedua, maka disusun perencanaan perbaikan untuk pelaksanaan pembelajaran yang terdiri dari (1) meningkatkan kemampuan siswa dalam diskusi, presentasi, dan penyusunan laporan hasil observasi, (2) meningkatkan keaktifan siswa dalam diskusi dan presentasi, (3) kemampuan siswa dalam bertanya dan menjawab pertanyaan belum merata, (4) menginformasikan sistematika yang baik dalam menyusun laporan, dan presentasi.

2. Pembelajaran pada siklus kedua 
Pelaksanaan pembelajaran pada siklus dua prosesnya sama dengan yang dilakukan pada pembelajaran siklus satu. Namun dalam perencanaan perbaikan, dilakukan sesuai dengan refleksi pada siklus ke satu.

Tabel 4. Penilaian kinerja siswa dalam diskusi kelompok

\begin{tabular}{ccccccc}
\hline $\begin{array}{c}\text { Kelom } \\
\text { pok }\end{array}$ & A & B & C & D & E & $\begin{array}{c}\text { Rata- } \\
\text { rata }\end{array}$ \\
\hline 1 & 81.2 & 77.6 & 73.6 & 73.4 & 82.2 & 77.60 \\
2 & 75.8 & 77.2 & 74.6 & 70.6 & 83.8 & 76.40 \\
3 & 75.8 & 86.4 & 67.2 & 84.6 & 72.4 & 77.28 \\
4 & 79.8 & 77.4 & 74.4 & 79.8 & 79.2 & 78.12 \\
5 & 78 & 80 & 70.6 & 79.8 & 73.8 & 76.44 \\
6 & 82.2 & 74.4 & 83.2 & 77.6 & 80.6 & 79.60 \\
7 & 81.8 & 74.4 & 80 & 77.4 & 76.6 & 78.04 \\
8 & 80.4 & 75.8 & 67.6 & 73.4 & 80 & 75.44 \\
\hline Rata- & 79.38 & 77.90 & 73.90 & 77.08 & 78.58 & 77.37 \\
rata & & & & & &
\end{tabular}

Keterangan:

A: kerja sama

B: kemampuan berpendapat

C: kemampuan menerima pendapat

D: kualitas berargumentasi

E: kemampuan membuat kesimpulan hasil diskusi

Berdasarkan tabel 4 bahwa skor rata-rata aspek yang dinilai untuk semua kelompok dalam satu kelas sebesar 77.37. Berdasarkan kriteria keberhasilan yang telah ditentukan menggunakan standar ketuntasan nilai diskusi $(>70)$, maka secara kelas sudah tuntas. Selain itu dari 40 siswa yang memiliki nilai proses diskusi $>70$ atau dinyatakan tuntas sudah mencapai 39 siswa atau 97,50 \% dari seluruh siswa.

Hasil pengamatan selama pelaksanaan pembelajaran, dalam kegiatan refleksi diperoleh beberapa kesimpulan yaitu kemampuan siswa untuk menyampaikan pendapat mengalami peningkatan, siswa yang aktif dalam diskusi semakin banyak, bahkan sebagian besar siswa aktif dalam diskusi, kemampuan siswa dalam menjawab pertanyaan mengalami banyak peningkatan, walaupun kualitas berargumentasi masih perlu ditingkatkan kualitasnya, siswa semakin meningkat kemampuannya dalam menyimpulkan hasil diskusi.
Selanjutnya penilaian kinerja siswa dalam presentasi hasil kerja kelompok sebagai berikut.

Tabel 5. Penilaian kinerja siswa dalam presentasi

\begin{tabular}{ccccccc}
\hline $\begin{array}{c}\text { Kelomp } \\
\text { ok }\end{array}$ & A & B & C & D & E & $\begin{array}{c}\text { Rata- } \\
\text { rata }\end{array}$ \\
\hline 1 & 71.2 & 77.6 & 71.8 & 79 & 76.4 & 75.2 \\
2 & 87.4 & 79.8 & 71.8 & 80.4 & 80.8 & 80.04 \\
3 & 84.4 & 84 & 88 & 78.4 & 81 & 83.16 \\
4 & 73.6 & 86.2 & 77.6 & 78.4 & 79 & 78.96 \\
5 & 77.8 & 79 & 79.2 & 78.4 & 84.4 & 79.76 \\
6 & 75 & 75.6 & 78.2 & 81.4 & 82.6 & 78.56 \\
7 & 74 & 75.8 & 79.6 & 74.8 & 79.2 & 76.68 \\
8 & 83.8 & 68.8 & 79.2 & 81.6 & 79.6 & 78.6 \\
\hline Rata- & 78.4 & 78.35 & 78.175 & 79.05 & 80.375 & 78.87 \\
rata & & & & & &
\end{tabular}

Keterangan:

A: kerja sama

B: Sistematika berbicara

C: kemampuan mengikuti presentasi

D: kualitas hasil observasi

E: kemampuan membuat kesimpulan

Berdasarkan tabel 5 bahwa skor rata-rata untuk semua aspek dalam satu kelas selama melaksanakan prestasi adalah sebesar 78.87. Berdasarkan kriteria keberhasilan yang telah ditentukan menggunakan standar ketuntasan nilai presentasi $(>70)$, maka secara kelas sudah tuntas. Selain itu dari 40 siswa yang memiliki nilai proses presentasi $>70$ adalah semua siswa, atau dinyatakan tuntas $100 \%$.

Selanjutnya guru juga melakukan penilaian terhadap laporan hasil kerja kelompok dengan menggunakan format penilaian proyek.Hasil penilaian kerja kelompok sebagai berikut.

Tabel 6. Penilaian proyek laporan hasil observasi kerja kelompok

\begin{tabular}{ccccccc}
\hline & \multicolumn{9}{c}{ Aspek yang Dinilai } & Rata- \\
Kelompok & A & B & C & D & E & rata \\
\hline 1 & 86 & 70 & 75 & 77 & 88 & 79.2 \\
2 & 88 & 68 & 72 & 80 & 87 & 79 \\
3 & 71 & 86 & 89 & 67 & 65 & 75.6 \\
4 & 72 & 87 & 89 & 66 & 66 & 76
\end{tabular}




\begin{tabular}{ccccccl}
5 & 80 & 68 & 68 & 70 & 89 & 75 \\
6 & 79 & 69 & 70 & 68 & 90 & 75.2 \\
7 & 68 & 85 & 71 & 73 & 80 & 75.4 \\
8 & 70 & 83 & 70 & 74 & 80 & 75.4 \\
\hline Rata-rata & 77 & 76.75 & 75.5 & 71.88 & 80.63 & 76.35
\end{tabular}

Keterangan:
A: kelengkapan isi laporan
B: sistematika laporan
C: kualitas laporan
D: Penggunaan bahasa
E: relevansi dengan tugas

Berdasarkan tabel 6 bahwa skor rata-rata untuk semua aspek dalam satu kelas untuk hasil laporan adalah sebesar 76.35. Berdasarkan kriteria keberhasilan dengan menggunakan standar ketuntasan nilai laporan pada siklus dua $(>70)$, maka secara kelas dianggap sudah tuntas. Selain itu semua kelompok memiliki nilai laporan > 70, sehingga semua atau $100 \%$ kelompok dinyatakan tuntas.

Setelah tahap pelaksanaan dan pengamatan dalam siklus dua berakhir, maka selanjutnya adalah tahap refleksi.Pada tahap refleksi ini dapat diidentifikasi kelebihandan kelemahan selama pelaksanaan pembelajaran siklus dua. Kelebihan selama pelaksanaan pembelajaran sebagai berikut: (1) siswa sangat antusias dengan kegiatan pembelajaran, (2) siswa lebih aktivitas selama proses belajar, (3) siswa menjadi lebih kreatif, hal ini dapat dilihat dari cara mereka menyajikan laporan ilmiah, penyusunan peta konsep, maupun dalam melaksanakan kegiatan kelompok, (4) siswa menjadi lebih komunikatif, (5) siswa berlomba untuk mendapatkan nilai terbaik (setiap ada keberhasilan guru selalu memberi reward), (6) konsentrasi siswa dalam belajar cukup tinggi, karena guru selalu membawa siswa masuk dalam orientasi masalah sebelum pembelajaran inti dimulai, (7) hasil belajar siswa dari kegiatan postes telah meningkat (dari rata-rata 73,22 menjadi 81,89 dan ketuntasan belajar secara klasikal dari $81,08 \%$ menjadi 88,89\%), (8) semua rencana perbaikan tindakan berdasarkan hasil refleksi siklus satu telah dilaksanakan di siklus dua dengan baik, dan (9) kinerja guru dalam melaksanakan dan mengelola pembelajaran semakin mantap, karena guru konsisten dalam melaksanakan pembelajaran, yaitu mengacu kepada rencana pembelajaran yang telah disusun sesuai dengan strategi pembelajaran yang dipilih.

Dengan demikian berdasarkan analisi data tersebut di atas menunjukkan bahwa pembelajaran kontekstual nampaknya memberikan dampak positif bagi peningkatan aktivitas belajar siswa dalam pembelajaran ekonomi. Siswa lebih aktif dan kreatif dalam proses pembelajaran yaitu pada saat diskusi kelompok dan presentasi hasil kerja kelompok. Melalui pembelajaran kontekstual, siswa lebih termotivasi dalam belajarnya, karena siswa dapat menghubungkan materi pembelajaran yang di dapat dengan aktivitas ekonomi yang ada di sekitar kehidupan mereka. Hasil penelitian ini sejalan dengan dengan penelitian yang diungkapkan oleh Nurhidayah \& Nurlina (2016); Susiloningsih (2016); Lilia \& Widodo (2014) bahwa pembelajaran ekonomi yang dilaksanakan oleh guru dengan menerapkan pembelajaran kontekstual terbukti memberikan dampak positif bagi peningkatan aktivitas dan hasil belajar siswa.

Selain itu hasil penelitian ini juga sesuai dengan penelitian yang diungkapkan oleh Retnanto (2016) dalam bahwa pembelajaran kontekstual membuat siswa lebih mudah memahami materi yang bersifat abstrak karena adanya keterkaitan materi pelajaran dengan kehidupan nyata yang ada disekitar kehidupan mereka. Dengan adanya pembelajaran yang mengaitkan materi pembelajaran ekonomi dengan aktivitas ekonomi yang ada disekitarnya, dapat membuat pembelajaran lebih menarik dan bermakna bagi mereka.

Selain itu dalam penelitian ini juga dapat menunjukkan bahwa pembelajaran kontekstual yang diterapkan oleh guru mampu membawa perubahan bagi aktivitas belajar siswa. Siswa lebih mudah untuk melakukan kerja sama dengan teman-temannya. Kemampuan siswa lebih meningkat dengan melakukan kerja kelompok. Dengan demikian hasil penelitian ini juga sesuai dengan penelitian yang diungkapkan oleh Pulungan dkk., (2013); Komalasari (2012) bahwa pembelajaran kontekstual dalam pembelajaran ekonomi mampu meningkatkan kecakapan personal dan kecakapan sosial siswa dalam bentuk kemampuan kerja sama dan bekerja dalam kelompok. 


\section{SIMPULAN}

Berdasarkan hasil penelitian tindakan kelas yang telah diterapkan di kelas X IPS 2 MAN 9 Jombang menunjukkan bahwa dalam siklus satu pembelajaran kontekstual yang diterapkan oleh guru belum efektif untuk meningkatkan kemampuan diskusi kelompok, presentasi hasil, dan laporan hasil kerja kelompok. Hal tersebut dapat terjadi karena proses penyesuaikan penerapan pembelajaran yang baru. Setelah diterapkan siklus ke dua, kemampuan diskusi kelompok, presentasi hasil, dan laporan hasil kerja kelompok meningkat dan dinyatakan tuntas berdasarkan kriteria keberhasilan yang telah ditetapkan. Dengan demikian pembelajaran kontekstual yang diterapkan oleh guru dalam mata pelajaran efektif untuk meningkatkan pemahaman dan aktivitas siswa selama diskusi dan presentasi hasil. Selain itu pelaksanaan pembelajaran kontekstual dapat meningkatkan hasil belajar siswa tentang materi uang dan lembaga keuangan. Direkomendasi untuk penelitian selanjutnya maupun kepada guru ekonomi untuk menerapkan pembelajaran kontekstual dalam pembelajaran ekonomi yang dipadukan dengan metode pembelajaran lain terutama metode pembelajaran yang berbasis observasi lapangan untuk meningkatkan kreativitas dan pengalaman kehidupan nyata.

\section{DAFTAR PUSTAKA}

Aqib, Z. (2013). Model-model, media, dan strategi pembelajaran kontekstual (inovatif). Bandung: Yrama Widya.

Hanafiah, N., \& Suhana, C. (2012).Konsep strategi pembelajaran. Bandung: Refika Aditama.

Johnson, E. B. (2002). Contextual teaching and learning: What it is and why it's here to Stay. California: Corwin Pres, Inc.

Komalasari, K. (2010). Pembelajaran kontekstual: Konsep dan aplikasi. Bandung: Refika Aditama.

Komalasari, K. (2012). The effect of contextual learning in civic education on students' civic skills. Educare, 4(2), 179-190.

Koshy, V. (2005).Action Research for Improving Practice: A Practical Guide. London: Paul Chapman Publishing.
Kunandar. (2007). Guru profesional implementasi kurikulum tingkat satuan pendidikan (KTSP) dan sukses dalam sertifikasi guru. Jakarta: PT Raja Grafindo Persada.

Lilia, L., \& Widodo, A.T. (2014). Implementasi pembelajaraan kontekstual dengan strategi percobaan sederhana berbasis alam lingkungan siswa kelas X. Jurnal Inovasi Pendidikan Kimia, 8(2), 1351-1359

Mulyasa, E. (2007). Profesionalisme Guru. Jakarta: Dirjen PMPTK.

Nurhidayah, Yani, A, \& Nurlina. (2016). Penerapan model contextual teaching learning (CTL) terhadap hasil belajar fisika pada siswa kelas XI SMA Handayani Sungguminasa Kabupaten Gowa. Jurnal Pendidikan Fisika, 4 (2), 161174.

Nurhadi, B. Yasin., \& A. G. Senduk. (2003). Pembelajaran kontekstual dan penerapannya dalam KBK. Malang: Universitas Negeri Malang.

Pulungan, N., Nurmaliah, C., \& Samingan.(2013). Pengaruh penerapan pembelajaran kontekstual pada kecakapan hidup siswa di MTsS Al-Washliyah Lhokseumawe.Jurnal EduBio Tropika, 1(2), Edisi Khusus, 61-120.

Retnanto, A. (2016). Aktualisasi pendekatan contextual teaching and learning (CTL) pada pembelajaran mata kuliah metodologi penelitian pendidikan di STAIN Kudus tahun 2016.Quality, 4(1), 140-162.

Sanjaya, W. (2008). Strategi pembelajaran: Berorientasi standar pendidikan. Jakarta: Kencana.

Santoso, E. (2017). Penggunaan model pembelajaran kontekstual untuk meningkatkan kemampuan pemahaman matematika siswa sekolah dasar (Studi pada siswa kelas V SDN Sukarasa II Kecamatan Samarang Kabupaten Garut tahun pelajaran 2014-2015).Jurnal Cakrawala Pendas, 3(1), 16-29.

Sung, Han-Yu., Hwang, Gwo-Jen., Chen, ChinYu., \& Liu, Wen-Xiu.(2019). A contextual learning model for developing interactive e-books to improve students'performances of learning the analects of 
Confucius.Interactive

Learning

Environments,DOI:10.1080/10494820.201

9.1664595

Trianto.(2007). Model pembelajaran terpadu dalam teori dan praktek. Jakarta: Prestasi Pustaka Publisher.

Trianto.(2012). Model-model pembelajaran inovatif berorientasi kontruktivisme. Jakarta: Prestasi Pustaka Raya.

Susiloningsih, W. (2016).Model pembelajaran CTL (contextual teaching and learning) dalam meningkatkan hasil belajar mahasiswa PGSD pada matakuliah konsep IPS dasar.Jurnal Pedagogia, 5(1), $57-66$ 